\title{
Resistance to cyanide by salicylate pretreatment in Salix babylonica L.
}

\author{
Rasoul Ghasemi1*, Razieh Mokhtari² \\ 'Department of Biology, Payame Noor University, Tehran, Iran. \\ ${ }^{2}$ Department of Biology, Payame Noor University, Isfahan, Iran. \\ *Corresponding author: ghasemi@nj.isfpnu.ac.ir \\ Received: 11 July 2013; Accepted: 14 November 2013
}

ABSTRACT: Cyanide is uncontrollably produced in some industrial operations and has lethal effects on humans and the environment. Since removing processes of cyanide are complicated and costly, the phytoremediation has recently been extensively considered. To achieve an increased cyanide resistance, which is needed for an efficient phytoremediation of the mediums with high concentrations of cyanide, the effects of salicylate as a phytohormone were studied. Cuttings of Salix babylonica, as a model plant, were used in a completely randomized design with three replicates in hydroponics using a modified Hoagland nutrient solution. Plants were pretreated with sulfosalicylate $\left(0,5,10\right.$ and $\left.15 \mathrm{mg} \mathrm{L}^{-1}\right)$ for 21 days and then were treated with toxic concentration of cyanide $\left(9 \mathrm{mg} \mathrm{CN}^{-} \mathrm{L}^{-1}\right)$; some of the physiological indices which show cyanide toxicity/resistance were measured. Favorable responses to salicylate toward the increase in resistance to cyanide were concentration dependent which were observed at $10 \mathrm{mg} \mathrm{L}^{-1}$ sulfosalicylate and it was accompanied with an increase in superoxide dismutase activity and reducing the capacity of root extract. Dehydrogenase activity and electrolyte leakage from roots were decreased relating to control plants. It also prevented the cyanide inhibitory effect on oxygen consumption. The observed effects could be attributed to redox status and alteration of production and scavenging of reactive oxygen species by salicylate and cyanide. The results indicated that a proper concentration of salicylate could be used as a cyanide resistance stimulator in willows.

KEYWORDS: redox status, respiration, ROS, SOD, tolerance.

ABBREVIATIONS: AOX: alternative oxidase, $\mathrm{CN}$ : cyanide, ROS: reactive oxygen species, IV complex: IV complex in mitochondrial respiratory chain, SOD: superoxide dismutase.

\section{INTRODUCTION}

Cyanide $\left(\mathrm{CN}^{-}\right)$is an anion composed of a carbon triply bonded to a nitrogen atom. This anion is one of the most lethal chemicals and highly used in different industries such as gold, lead and zinc extraction and also in the production of nylon and plastics. In addition to the regular usages of $\mathrm{CN}^{-}$, it is a byproduct of some industrial processes in which high concentrations of carbon and nitrogen are put together in a hot and reducing condition, such as chemical manufacturing, iron and steel making, petroleum refining, and aluminum smelting. The free $\mathrm{CN}^{-}$, whatever its sources, finally enters into the wastewater or releases to the environment which, if possible, must be refined. Different methods are usually used for $\mathrm{CN}^{-}$detoxification including naturally scavenging of $\mathrm{CN}^{\text {; }}$, alkaline chlorination and oxidation using hydrogen peroxide. Management of $\mathrm{CN}^{-}$using chemical processes is costly, complicated and usually some new harmful byproducts are produced. Indeed, the phytoremediation of $\mathrm{CN}^{-}$has recently been paid attention to. Phytoremediation is the use of vascular plants, algae, and fungi to metabolize or sequester contaminants, or to induce contaminant breakdown by microorganisms in soil (McCutcheon and Schnoor 2003).

Although $\mathrm{CN}^{-}$is a highly toxic substance and has a high potential to prevent different metabolic pathways, there are almost 2,000 species known as cyanogenic plants which produce high amounts of $\mathrm{CN}^{-}$(mainly as glucosides) for 
defense purpose (Halkier and Møller 1990). In addition, in all vascular plants and in some of the algae and fungi, it is produced as a byproduct during the synthesis of ethylene. Since plants, similarly to the other organisms, are sensitive to $\mathrm{CN}$, they must hold different strategies for scavenging the produced $\mathrm{CN}$.

$\mathrm{CN}^{-}$affects general metabolism of the cells through blocking of electron transport chain in mitochondria and chloroplasts, decreasing oxygen consumption and inhibiting the activity of some of the metal containing enzymes such as $\mathrm{Cu}$ and $\mathrm{Zn}$ isoform of superoxide dismutase $(\mathrm{Cu} / \mathrm{Zn} \mathrm{SOD})$. The change in the cells' energy status and the malfunction of cellular protective enzymes could induce disintegration in membranes and electrolyte leakage from the cells. Plant mitochondria contains a $\mathrm{CN}^{-}$resistant electron transport chain called alternative oxidase (AOX) by which they are able to tolerate increased concentrations of $\mathrm{CN}^{-}$. In addition, different metabolic pathways, such as cyanoalanine pathway (Tittle et al. 1990), make it possible to metabolize $\mathrm{CN}^{-}$by plants. Indeed, the plants could have significant potential for the phytoremediation of $\mathrm{CN}$.

Willow (Salix spp.) has been considered a promising model plant in the studies of $\mathrm{CN}^{-}$phytoremediation (Ebbs et al. 2006). Desirable properties of willows for phytoremediation are: fast growth and accumulation of high biomass, high abilities to uptake water and chemicals from the environment, and high water evaporation rates. Bushey et al. (2006a) showed that the destination of $\mathrm{CN}^{-}$after uptake by Salix eriocephala is the assimilation into some of the cellular metabolites, as its evaporation from the plant is negligible. Different studies have been performed with the aim of modeling a practical $\mathrm{CN}^{-}$ phytoremediation (Bushey et al. 2006a, 2006b). For instance, uptake and translocation of $\mathrm{CN}^{-}$in free and other forms have been observed in different plant species such as Hordeum vulgar, Sorghum bicolor, Eucalyptus spp., Avena sativa and Salix eriocephala (Ebbs et al. 2003, 2008, Samiotakis and Ebbs 2004). It has also shown that some of the physiological conditions, such as nitrogen nutrition status and environmental stresses like water deficiency, induce the assimilation pathways of $\mathrm{CN}^{-}$(Ebbs et al. 2010, Machingura and Ebbs 2010, Machingura et al. 2013).

The increase of the AOX ability and metabolizing pathways have special importance in the phytoremediation of $\mathrm{CN}$. Salicylate as a plant hormone strongly stimulates AOX (Van der Straeten et al. 1995). In addition, it stimulates reactive oxygen species (ROS) production and scavenging systems in plants (Hayat et al. 2007). In this study, the effects of salicylate on the resistance of Salix babylonica to $\mathrm{CN}^{-}$were investigated. Some of the potential or known responses of plants to salicylate and $\mathrm{CN}^{-}$were tested to conclude about the responsible mechanisms of acquired resistance. The metabolic and other response pathways overlapped in the responses to both salicylate and $\mathrm{CN}^{-}$are targets of this study. We also measured the responses simultaneously in order to attain a more comprehensive view on these interactions.

\section{MATERIAL AND METHODS}

Preparing the cuttings and culture medium: Cuttings with 150 to $200 \mathrm{~mm}$ long were prepared from semi-woody two-year old branches of a Salix babylonica tree in late spring of 2011. Cuttings were placed in perlite by half of the length from base, watered with tap water and kept in a growth chamber with a light regime of 16:8 (light:dark) constant temperature of $24^{\circ} \mathrm{C}$. The rooting of the cuttings occurred after $25 \mathrm{~d}$. A hydroponic culture was used for the treatment of plants. The cuttings were then transferred to the greenhouse in pots containing $10 \mathrm{~L}$ of a modified Hoagland solution $\mathrm{pH} 5.8$, containing $0.5 \mathrm{mM}$ $\mathrm{CaNO}_{3}, 0.5 \mathrm{mM} \mathrm{MgSO}_{4}, 0.1 \mathrm{mM} \mathrm{KH}_{2} \mathrm{PO}_{4}, 0.5 \mathrm{mM} \mathrm{KNO}_{3}$ $0.005 \mathrm{mM}$ FeEDDHA (Ferric ethylenediamine-di-2hydroxyphenylacetate), $0.01 \mathrm{mM} \mathrm{H}_{3} \mathrm{BO}_{3}, 2 \mu \mathrm{M} \mathrm{MnCl}_{2}, 0.2$ $\mu \mathrm{M} \mathrm{ZnSO}_{4}, 0.2 \mu \mathrm{M} \mathrm{CuSO}_{4}$ and $0.1 \mu \mathrm{M} \mathrm{Na}_{2} \mathrm{MoO}_{4}$.

The solutions were aerated periodically every $3 \mathrm{~h}$ and exchanged every $10 \mathrm{~d}$. Evaporation was compensated daily by adding distilled water to the solutions. The plants were kept in this situation until complete adaptation to the greenhouse conditions. Then, the experiments were performed in the greenhouse during the late spring and summer. The range of temperature during the day was $25-36^{\circ} \mathrm{C}$ and in the night was $22-25^{\circ} \mathrm{C}$.

Although the $\mathrm{pH}$ of the Hoagland solution had been adjusted to 5.8, after the addition of $\mathrm{CN}^{-}$the solution $\mathrm{pH}$ was adjusted to 7.8 to reduce evaporation of $\mathrm{CN}^{-}$, which occurs at lower $\mathrm{pH}$. Since $\mathrm{CN}^{-}$complexes with different metals and the complexes are not easily absorbed by plants, the concentration of culture solutions were reduced $1 / 10$ to diminish complex formation after the treatment of plants with $\mathrm{CN}$.

\section{Pre-treatment by salicylate and treatment of plants by cyanide: Two plants were transferred into pots containing} 1.5 L culture solution before the treatments. Plants with even weights were selected and the total weight of each plant was $120 \pm 10 \mathrm{~g}$. The plants were pre-treated with different concentrations of sulfosalicylate including $0,5,10$ and $15 \mathrm{mg} \mathrm{L}^{-1}$ for 2 weeks. The treatment with $\mathrm{CN}^{-}$was performed by using $\mathrm{NaCN}$ at a toxic concentration of $9 \mathrm{mg} \mathrm{CN}^{-}$for $24 \mathrm{~h}$. The toxicity threshold of $\mathrm{CN}^{-}$concentration was determined by submitting the plants to different concentrations of $\mathrm{CN}^{-}$at 
0, 3, 5, 9, 15 and $20 \mathrm{mg} \mathrm{CN}^{-} \mathrm{L}^{-1}$. After the treatments, different parameters including oxygen consumption by roots, leakage of electrolytes from roots, reducing capacity of root extract, dehydrogenase and superoxide dismutase activities in roots were measured.

Measurement of oxygen consumption: The roots were cut ( $1 \mathrm{~g} \mathrm{FW}$, fresh weight), washed twice with distilled water and then transferred into test tubes containing $45 \mathrm{~mL}$ of distilled water. Dissolved oxygen was measured every $2 \mathrm{~h}$ using an oxygen meter (WTW with an electrode model Cellox 325, Germany). The oxygen meter was calibrated before use based on the device manual.

Measurement of the electrolyte leakage: After harvesting, $1 \mathrm{~g}$ FW of root from each treatment was subjected to desorption using an ice cooled desorption solution containing $5 \mathrm{mM} \mathrm{CaSO}_{4}$ and $5 \mathrm{mM} \mathrm{Na}_{2}$ EDTA, pH 5.8, for $10 \mathrm{~min}$, and then washed twice with bidistilled water. The roots were then transferred into test tubes containing $45 \mathrm{~mL}$ of bidistilled water and shaken very gently at $50 \mathrm{rpm}$. The electrical conductivity (EC) of the water was measured every $2 \mathrm{~h}$ until $6 \mathrm{~h}$, using an EC-meter (Elmetron, Poland).

Reducing capacity test: The reducing capacity of the extract was measured based on the ferric reducing antioxidant power (FRAP) test (Benzie and Strain 1999). A section of root $(1 \mathrm{~g} \mathrm{FW})$ was grinded with liquid nitrogen using an ice cooled mortar and pestle. Then, $3 \mathrm{~mL}$ of $50 \mathrm{mM}$ phosphate buffer, $\mathrm{pH} 6$, were added and after more grinding the extracts were centrifuged at $12,000 \mathrm{x} g$ at $4^{\circ} \mathrm{C}$ for $10 \mathrm{~min}$. In all steps, the temperature was kept below $4^{\circ} \mathrm{C}$. The reducing capacity was performed using of TPTZ (2,4,6-tri(2-pyridyl)-1,3,5triazine). At low $\mathrm{pH}$, reducing $\mathrm{Fe}^{3+}$ to $\mathrm{Fe}^{2+}$ by reducing agents of the extract causes an intense blue color after the formation of TPTZ-Fe ${ }^{2+}$ complex, with an absorption peak at $593 \mathrm{~nm}$. A standard curve was obtained using different concentrations of $\mathrm{FeSO}_{4}$ which was linear between 10 and $100 \mu \mathrm{M} \mathrm{FeSO}_{4}$.

Measurement of dehydrogenase activity. Dehydrogenase activity was measured according to Kittock and Law (1968) by using $20 \mathrm{~g} \mathrm{FW}$ of root submerged in $1 \mathrm{~mL}$ of $1 \%$ TTC (2,3,5 three-phenyltetrazolium-chloride) solution for $2 \mathrm{~h}$. The roots were then submerged into $3 \mathrm{~mL}$ of methyl cellosolve (2-methoxyethanol) solvent and gently shaken for $6 \mathrm{~h}$ until the roots became white. The solution was then separated and centrifuged at $10,000 \times \mathrm{g}$ for $10 \mathrm{~min}$. Finally, the absorption was measured at $480 \mathrm{~nm}$ and the results were expressed as percentage of the control plants.
Measurement of the superoxide dismutase activity: The activity of SOD (1.15.1.1) was measured according to Giannopolitis and Ries (1997). The reaction solution contained $50 \mathrm{mM}$ buffer phosphate, $\mathrm{pH}$ 7.8, $13 \mathrm{mM}$ methionine, $75 \mu \mathrm{M}$ NBT ( $\rho$-nitrobluetetrazolium chloride), $2 \mu \mathrm{M}$ riboflavin and $0.1 \mathrm{mM}$ EDTA. The reaction was started by adding $100 \mu \mathrm{L}$ of root extract (from the preparation above mentioned) to $1,000 \mu \mathrm{L}$ of reaction solution, mixed and put under florescence light with the intensity of $30 \mu \mathrm{mol}$ photon $\mathrm{m}^{-2} \mathrm{~s}^{-1}$ for $15 \mathrm{~min}$. Using dark samples as blank, the absorption was measured at $560 \mathrm{~nm}$. Based on definition, half of the reaction of converting of NBT (yellowish) to Formazan (gray-bluish) is defined as a unit of SOD activity.

Measurement of cyanide in medium: A colorimetric method was used to measure $\mathrm{CN}^{-}$in medium (Goulden et al. 1972 ) by adding $1 \mathrm{~mL}$ of $1 \mathrm{M} \mathrm{NaOH}$ and $1 \mathrm{~mL}$ of $0.4 \%$ of chloramine $\mathrm{T}$ to $5 \mathrm{~mL}$ of each sample. The mixture was kept for $2 \mathrm{~min}$ and then $1 \mathrm{~mL}$ of pyridinebarbituric acid was added to each sample. The mixture was kept for 5 min during which time a purple color appeared. Light absorption at $578 \mathrm{~nm}$ was measured. Using a standard curve (at the range concentration of 0.02-0.2 $\mathrm{mg} \mathrm{CN}^{-} \mathrm{L}^{-1}$ ), the concentration of $\mathrm{CN}^{-}$in medium was determined.

Statistical analyses: The experiments were performed in a complete randomized design. To determine the statistically significant differences between the means, multiple comparisons were performed by one way ANOVA and Tukey's HSD test. The Statistical Package for the Social Sciences (SPSS) software (version 16 for Windows; SPSS Inc., Chicago, IL, USA) was used for statistical analyses. The reported data are the means for 3 replicates \pm SD.

\section{RESULTS}

Resistance was studied from two viewpoints. Firstly, from the occurrence of toxicity symptoms in plants and second from the duration between the treatment and the occurrence of the symptoms. In high concentrations of $\mathrm{CN}^{-}$, the roots turned brownish and the shoots were dried without necrosis, destruction of chlorophyll or shedding of leaves. In moderate concentrations of $\mathrm{CN}^{-}$, growth depression of the apical meristems, shedding of leaves and yellowing of leaf interveins were observed. At non-toxic concentrations, none of the symptoms were observed. Acute symptoms appeared at the concentrations of 15 and $20 \mathrm{mg} \mathrm{CN}^{-} \mathrm{L}^{-1}$ after $24 \mathrm{~h}$. Moderate symptoms of toxicity at $9 \mathrm{mg} \mathrm{L}^{-1}$ were observed after $48 \mathrm{~h}$. At the concentrations of 3 and $5 \mathrm{mg} \mathrm{CN}^{-} \mathrm{L}^{-1}$, no toxicity was observed. The results also showed that pretreatment of 
plants with sulfosalicylate reduced the symptoms at 9 $\mathrm{mg} \mathrm{L}^{-1} \mathrm{CN}^{-}$. After $24 \mathrm{~h}$, some moderate symptoms were observed but they did not persist and the plants returned to normal growth.

Table 1 shows the viability of pretreated plants after being treated by toxic concentration of $\mathrm{CN}^{-}\left(9 \mathrm{mg} \mathrm{CN}^{-} \mathrm{L}^{-1}\right)$. Pretreatment by sulfosalicylate caused statistically significant increase in plant viability after the treatment by lethal concentration of $\mathrm{CN}^{-}\left(9 \mathrm{mg} \mathrm{CN}^{-} \mathrm{L}^{-1}\right)$ in $48 \mathrm{~h}$. Among the different concentrations of sulfosalicylate used, $10 \mathrm{mg}$ $\mathrm{L}^{-1}$ showed the highest viability.

The amounts of consumed $\mathrm{CN}^{-}$by pretreated plants are shown in Figure 1. In all treatments, more than 95\% of the added $\mathrm{CN}^{-}$was absorbed by roots. The highest consumption was observed by control and at $5 \mathrm{mg} \mathrm{L}^{-1}$ sulfosalicylate pretreated plants. By increasing the concentration of sulfosalicylate, less uptake of $\mathrm{CN}^{-}$was observed $(\mathrm{p}<0.05)$.

Figure 2 shows the oxygen consumption by roots treated with different concentrations of sulfosalicylate. In $\mathrm{CN}^{-}$treated plants which were not treated with

Table 1. Viability of the sulfosalicylate pretreated plants (Salix babylonica) treated by $9 \mathrm{mg} \mathrm{CN}^{-} \mathrm{L}^{-1}$ in 48 and $72 \mathrm{~h}$. Amounts are expressed as percentage of viable plants

\begin{tabular}{ccc}
$\begin{array}{c}\text { Sulfosalicylate concentration } \\
\left(\mathrm{mg} \mathrm{L}^{-1}\right)\end{array}$ & \multicolumn{2}{c}{ Viability (\%) } \\
\cline { 2 - 3 } & $48 \mathrm{~h}$ & $72 \mathrm{~h}$ \\
5 & 50 & 0 \\
10 & 100 & 66.6 \\
\hline 15 & 100 & 100 \\
\hline & 66.6 & 50 \\
\hline
\end{tabular}

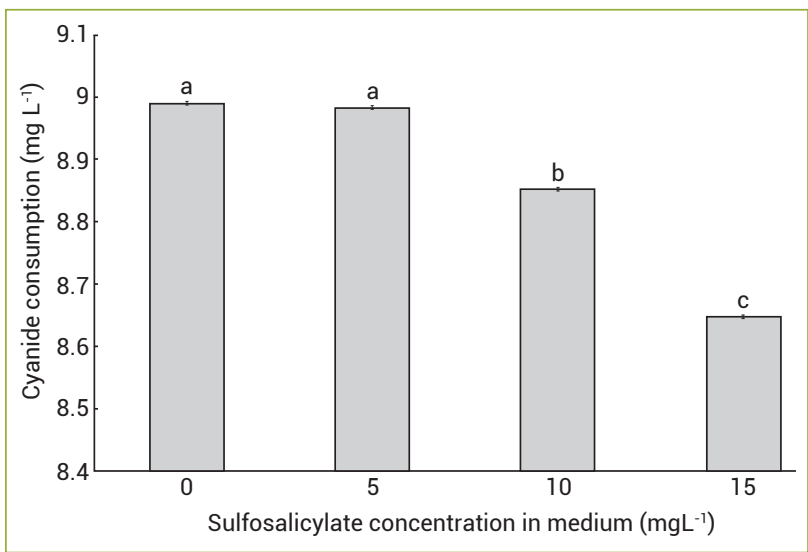

Figure 1. Consumption of cyanide by salicylate pretreated plants during $24 \mathrm{~h}$. Bars represent arithmetic means $\pm S D$ of $n=3$ replicate samples, each containing 2 plants. Different letters show statistically significant differences $(p<0.05)$ between different concentrations of sulfosalicylate based on ANOVA (Tukey's HSD test). sulfosalicylate, a significant decrease in oxygen consumption was observed $(\mathrm{p}<0.01)$ while no decrease was observed in sulfosalicylate treated plants.

The treatment with $\mathrm{CN}^{-}$induced electrolyte leakage from roots $(\mathrm{p}<0.05)$. In comparison to the control plants with no pretreatment of salicylate, less leakage of electrolytes was observed from the roots that were pretreated with $10 \mathrm{mg} \mathrm{L}^{-1}$ sulfosalicylate (Figure 3). Pretreatment by 5 and $15 \mathrm{mg} \mathrm{CN}^{-} \mathrm{L}^{-1}$ caused no change or even induced an increase in electrolyte leakage.

The dehydrogenase activity in roots was decreased with $\mathrm{CN}^{-}(\mathrm{p}<0.01)$. By increasing the concentration of sulfosalicylate from 5 to 10 and $15 \mathrm{mg} \mathrm{L}^{-1}$, a substantial decrease in dehydrogenase activity was observed (Figure 4). The results showed that the SOD activity was significantly increased $(\mathrm{p}<0.05)$ in $\mathrm{CN}^{-}$treated plants. Pretreatment of plants by sulfosalicylate also had a more stimulatory effect which was statistically significant at $10 \mathrm{mg} \mathrm{CN}^{-} \mathrm{L}^{-1}$ added to the medium $(\mathrm{p}<0.05$; Figure 5$)$.

The treatment by $\mathrm{CN}^{-}$in non-pretreated plants was accompanied by a significant decrease in reducing capacity, while at $15 \mathrm{mg} \mathrm{L}^{-1}$ sulfosalicylate no change was observed. At the pretreatments of 5 and $10 \mathrm{mg} \mathrm{L}^{-1}$ sulfosalicylate, a significant increase was observed as compared with the control non-pretreated plants $(\mathrm{p}<0.05$; Figure 6$)$.

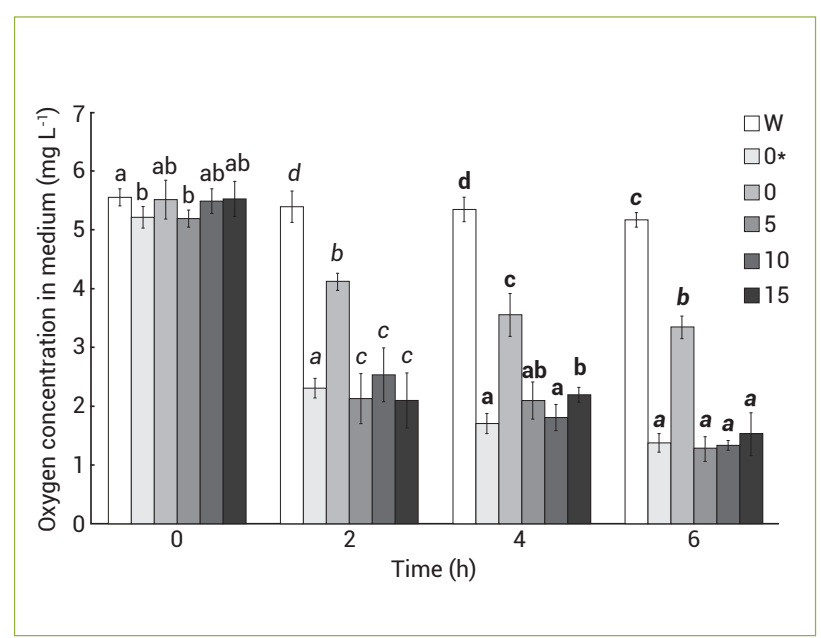

Figure 2. Effect of pretreatment of different concentrations of sulfosalicylate and treatment of toxic concentration of cyanide ( $9 \mathrm{mg} \mathrm{CN}^{-} \mathrm{L}^{-1}$ ) on the oxygen consumption by Salix babylonica roots. Bars represent arithmetic means $\pm S D$ of $n=3$ replicate samples, each containing 2 plants. Different letters in each series of time (normal letters for the time of 0 , italicized letters for $2 \mathrm{~h}$, bold letters for $4 \mathrm{~h}$ and italicized bold letters for $6 \mathrm{~h}$ ) show statistically significant differences $(p<0.05)$ between different concentrations of sulfosalicylate and control plants based on ANOVA (Tukey's HSD test). W: water without root; $0 *$ : roots without neither pretreatment of sulfosalicylate nor treatment of cyanide; 0 , 5, 10 and 15: pretreatment of 0 to $15 \mathrm{mg} \mathrm{L}^{-1}$ sulfosalicylate. 


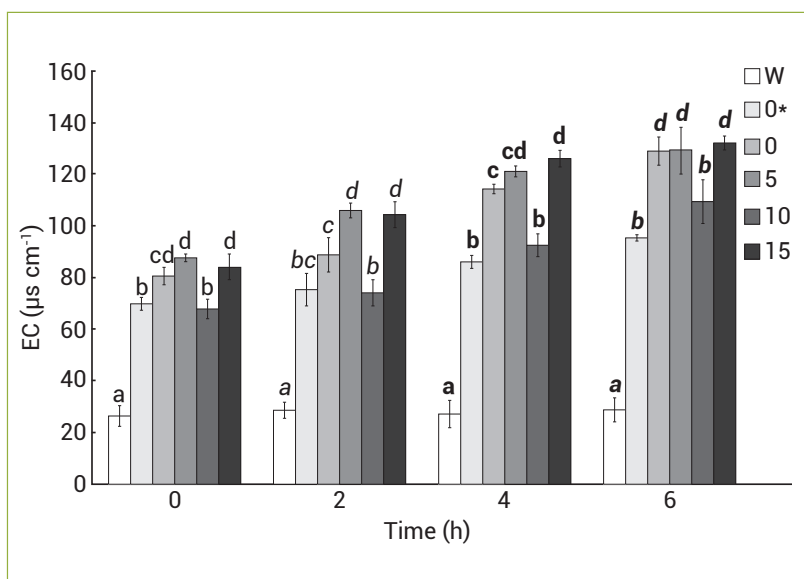

Figure 3. Effect of pretreatment of different concentrations of sulfosalicylate and treatment of toxic concentration of cyanide $\left(9 \mathrm{mg} \mathrm{CN}^{-} \mathrm{L}^{-1}\right)$ on the leakage of electrolytes from Salix babylonica roots. Bars represent arithmetic means $\pm S D$ of $n=3$ replicate samples, each containing 2 plants. Different letters in each series of time (normal letters for the time of 0 , italicized letters for $2 \mathrm{~h}$, bold letters for $4 \mathrm{~h}$ and italicized bold letters for 6 h) show statistically significant differences $(p<0.05)$ between different concentrations of sulfosalicylate and control plants based on ANOVA (Tukey's HSD test). EC: electrical conductivity; W: water without root; $0 *$ : roots without neither pretreatment of sulfosalicylate nor treatment of cyanide; $0,5,10$ and 15 : pretreatment of 0 to $15 \mathrm{mg} \mathrm{L}^{-1}$ sulfosalicylate.

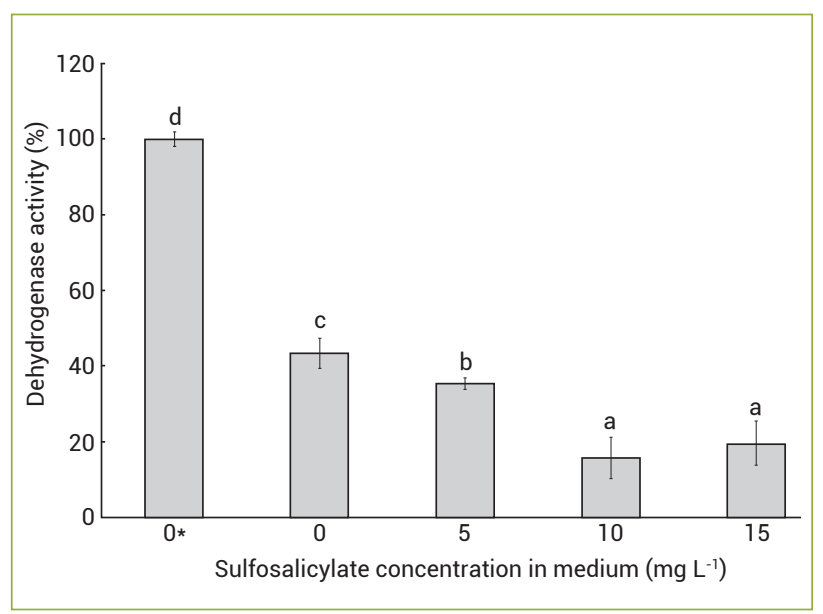

Figure 4. Dehydrogenase activity of the Salix babylonica roots pretreated by different concentrations of sulfosalicylate and treated with $9 \mathrm{mg} \mathrm{L}^{-1}$ cyanide. Bars represent arithmetic means $\pm S D$ of $n=3$ replicate samples, each containing 2 plants. Different letters show statistically significant differences $(p<0.01)$ between different concentrations of sulfosalicylate based on ANOVA (Tukey's HSD test). $0 *$ : roots without neither pretreatment of sulfosalicylate nor treatment of cyanide.

\section{DISCUSSION}

Plants could be considered as $\mathrm{CN}^{-}$consumers since, during the metabolism of the ethylene, it is produced with the ratio of 1:1 (Taiz and Zeiger 2002) and the produced $\mathrm{CN}^{-}$should be metabolized or released from tissues. In studies focusing

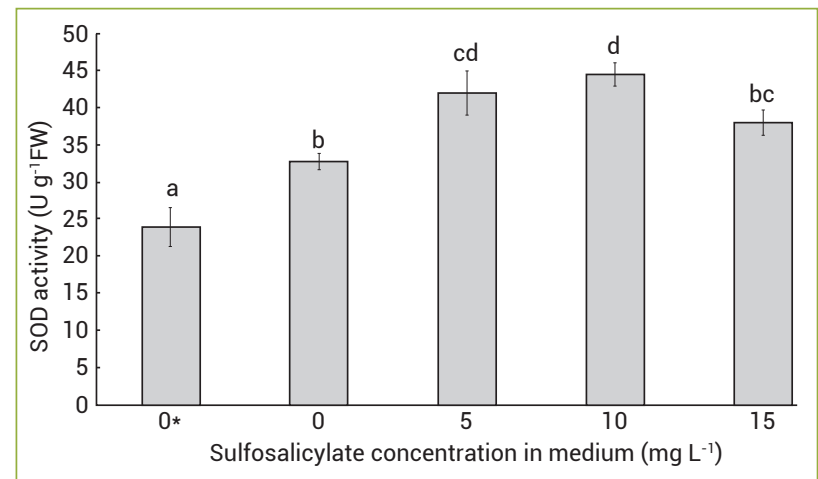

Figure 5. Superoxide dismutase activity of the Salix babylonica roots pretreated by different concentrations of sulfosalicylate and treated with $9 \mathrm{mg} \mathrm{L}^{-1}$ cyanide. Bars represent arithmetic means $\pm S D$ of $n=3$ replicate samples, each containing 2 plants. Different letters show statistically significant differences $(p<0.01)$ between different concentrations of sulfoalicylate based on ANOVA (Tukey's HSD test). $0 *$ : roots without neither pretreatment of sulfosalicylate nor treatment of cyanide; SOD: superoxide dismutase.

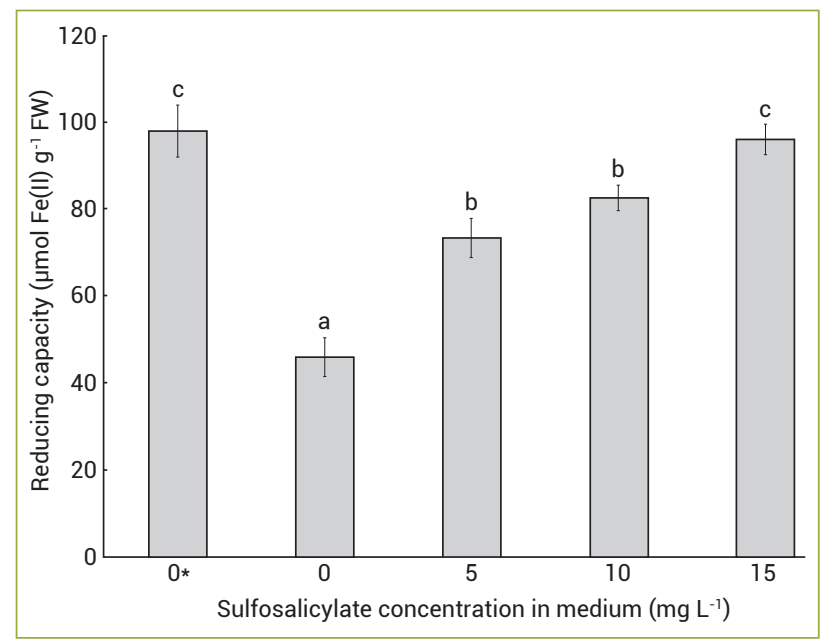

Figure 6. Reducing capacity of the Salix babylonica root extracts pretreated by different concentrations of sulfosalicylate and treated with $9 \mathrm{mg} \mathrm{L}^{-1}$ cyanide. Bars represent arithmetic means $\pm S D$ of $n=3$ replicate samples, each containing 2 plants. Different letters show statistically significant differences $(p<0.01)$ between different concentrations of sulfosalicylate based on ANOVA (Tukey's HSD test).

the resistance of plants to the unfavorable chemical agents, an important question is whether the resistant plant is able to metabolize the agent. In other words, do plants convert the toxic agent to a non-toxic form? Some studies have shown that no clear correlation could be found between resistance against the unfavorable agent and its detoxification (Mauricio 2000, Rausher 1992). Resistance is a mechanism that moderate the damage on the plant and tolerance is the ability of a plant to 
experience the damage devoid of reduction in the vigor (Baker 1987, Rausher 1992). To achieve this condition, plant metabolism interferes with structure and properties of enzymatic systems and changes the physico-chemical properties of cell membranes and transporters. Resistance to $\mathrm{CN}^{-}$may be due to the metabolization and destroying of the $\mathrm{CN}^{-}$and, in plants which have evolved mechanism(s) of ameliorating, the effects of $\mathrm{CN}^{-}$, the activities of metabolic pathways such as sulfur transferase and cyanoalanine have positive correlation with $\mathrm{CN}^{-}$resistance (Blumenthal et al. 1968, Castric et al. 1972).

Immediate metabolization of $\mathrm{CN}^{-}$in different cellular metabolizing pathways prevents $\mathrm{CN}^{-}$from reaching sensitive sites such as metals in metalloproteins. More active metabolizing pathways means less concentration of $\mathrm{CN}^{-}$in the cells and more resistance to higher concentrations of external $\mathrm{CN}$. Since the activity of different metabolizing pathways strongly is affected by the status of nutrition, energy, hormones and environmental conditions (Goudey et al. 1989; Tittle et al. 1990), resistance to cyanide changes by change in remarked factors.

One of the phytohormones which strongly affects the energy status and respiratory activities of the cells is salicylate (Hayat et al. 2007). This hormone strongly affects electron transport chain in mitochondria. The effect of salicylate on cellular respiration is concentrationdependent (Xie and Chen 1999). However, in the current study, no difference was observed in oxygen consumption at different concentrations of salicylate. It has a dual role in the production of ROS in the cells. If salicylate promotes disturbing in the respiration chain in mitochondria, more ROS are produced (Maxwell et al. 2002). The reason could be a mechanism like $\mathrm{CN}^{-}$and antimycine A - both inhibit the oxidation of cytochrome c (Chen et al. 1993). On the other hand, salicylate is one of the most important stimulators of $\mathrm{CN}^{-}$resistant respiratory pathway or AOX pathway (Rhoads and McIntosh 1992). Therefore, salicylate is an inhibitor of electron transport that increases ROS production and also activates AOX, which by consuming reducing agents prevents ROS production. In this study, we observed that the activity of SOD increased at the presence of salicylate. This finding could be due to an increase in the production of ROS by salicylate and $\mathrm{CN}^{-}$and consequently stimulation of antioxidant system of the cells (such as SOD). $\mathrm{CN}^{-}$inhibits not only electron transport chain at the IV complex in mitochondrial respiratory chain (IV complex) but also some of the metalloenzymes such as $\mathrm{Cu} / \mathrm{Zn}$ containing a form of superoxide dismutase $(\mathrm{Cu} / \mathrm{Zn} \mathrm{SOD})$, which is the most important isoform of SOD in cytosol (Tsang et al. 1991).

In this study, the treatment by $\mathrm{CN}^{-}$decreased the reducing power of the root extracts, which were not pretreated by salicylate. This result is possibly due to high production of oxidizing agents (such as ROS). The pretreatment of salicylate increased the reducing capacity, but it was not different of the control plants. The effect of salicylate could be due to preventing ROS production.

Enzymatic dehydrogenase activity in the root cells was decreased by $\mathrm{CN}$. We hypothesized that the long time pretreatment with salicylate and its inhibitory effect on electron transport chain, which occurs at the site of reduction of ubiquinone (Norman et al. 2004), could reduce the electron transport. By comparing with different studies, Galis and Matsuoka (2007) concluded that several hundreds of genes could be modulated by to salicylic acid including dehydrogenases. Therefore, it is pondered that the redox status of the cells is affected by salicylate by changing the activity of dehydrogenases.

ROS has a central role in maintaining the homeostasis of redox state of cells and the increase or decrease in their concentrations affects the activity of producing or scavenging pathways (Mittler 2002). We also observed that salicylate increased ion leakage from the roots (except at the concentration of $10 \mathrm{mg} \mathrm{L}^{-1}$ sulfosalicylate). Ion leakage is a result of high concentrations of ROS in the cells, as it causes lipid oxidation and impairs cellular membranes integrity, whose physiological consequence is ion leakage (Dietz et al. 1999).

It could be hypothesized that salicylate affected the cellular homeostasis by increasing the ROS production, which subsequently increased the activity of SOD and the activation of AOX. Increased activity of AOX prevents the decrease in oxygen consumption at the presence of $\mathrm{CN}^{-}$and favors the cells with ATP production at low rates. The most important findings of this study are summarized in Table 2.

The results suggest that, to increase resistance of plants against $\mathrm{CN}^{-}$, a concentration dependent pretreatment of salicylate might be used. In addition, measured resistance parameters will be useful to assess the activity of the $\mathrm{CN}^{-}$ consuming or metabolizing pathways with the salicylate pretreatment since the activity of these pathways is considered as resistance index. 
Table 2. Summarized results of the current study and a short description on the most possible reasons of the observed results. The results are a comparison between pretreated $\left(10 \mathrm{mg} \mathrm{L}^{-1}\right)$ or other concentrations $\left(5\right.$ and $\left.15 \mathrm{mg} \mathrm{L}^{-1}\right)$ of sulfosalicylate and control plants. Proper concentration of sulfosalicylate was defined based on the occurrence of a noticeable resistance

\begin{tabular}{|c|c|c|c|}
\hline \multirow[b]{2}{*}{ Measured } & \multicolumn{2}{|c|}{ Result } & \multirow[b]{2}{*}{ Description } \\
\hline & $\begin{array}{l}\text { Proper concentration of } \\
\text { sulfosalicylate }\left(10 \mathrm{mg} \mathrm{L}^{-1}\right)\end{array}$ & $\begin{array}{l}\text { Other used concentrations } \\
\text { of sulfosalicylate }\end{array}$ & \\
\hline SOD activity & Increase & Equal or increase & $\begin{array}{l}\text { Proper concentration showed the most } \\
\text { stimulation resulted in appropriate ROS scavenge }\end{array}$ \\
\hline Oxygen consumption & Increase & Increase & $\begin{array}{l}\text { Possibly due to activation of AOX pathway } \\
\text { by salicylate }\end{array}$ \\
\hline Electrolyte leakage & Decrease & Equal or increase & $\begin{array}{l}\text { A balanced cellular redox status and ROS } \\
\text { production/scavenge at proper concentration of } \\
\text { salicylate and keeping membrane integrity }\end{array}$ \\
\hline Dehydrogenase activity & Decrease & Decrease & $\begin{array}{l}\text { Inhibition by cyanide after treatment or hormonal } \\
\text { effect of salicylate on gene expression }\end{array}$ \\
\hline Reducing capacity & Increase & Increase & $\begin{array}{l}\text { Accumulation of reducing agent(s) due to } \\
\text { inhibition of electron transport chain }\end{array}$ \\
\hline $\begin{array}{l}\text { Uptake of cyanide from } \\
\text { medium }\end{array}$ & Decrease & Equal or decrease & $\begin{array}{l}\text { In the cases of decrease, still more than } 95 \% \text { of } \\
\text { added cyanide into the medium }\end{array}$ \\
\hline $\begin{array}{l}\text { Resistance to lethal } \\
\text { concentration of cyanide }\end{array}$ & Best result & Less suitable & $\begin{array}{l}\text { Salicylate can be used to increase resistance in } \\
\text { a concentration dependent mode }\end{array}$ \\
\hline
\end{tabular}

SOD: superoxide dismutase; ROS: reactive oxygen species; AOX: alternative oxidase.

\section{REFERENCES}

Baker AJM (1987) Metal tolerance. New Phytologist 106:93-111.

Benzie FF, Strain JJ (1999) Ferric reduction/antioxidant power assay: direct measure of total antioxidant activity of biological fluids and modified version for simultaneous measurement of total antioxidant power and ascorbic acid concentration. Methods in Enzymology 299:15-23.

Blumenthal SG, Hendrickson HR, Abrol YP, Conn EE (1968) Cyanide metabolism in higher plants. III. The biosynthesis of cyanoalanine. Biological Chemistry 243:5302-5307.

Bushey JT, Ebbs SD, Dzombak DA (2006a) Development of a plant uptake model for cyanide. International Journal of Phytoremediation 8:25-43.

Bushey JT, Small MJ, Dzombak DA, Ebbs SD (2006b) Parameter estimation of a plant uptake model for cyanide: application to hydroponic data. International Journal of Phytoremediation 8:45-62.

Castric PA, Farnden KJF, Conn EE (1972) Cyanide metabolism in higher plants. V. The formation of asparagine from $\beta$-cyanoalanine. Archives of Biochemistry and Biophysics 152:62-69.

Chen Z, Silva H, Klessig DF (1993) Active oxygen species in the induction of plant systemic acquired resistance by salicylic acid. Science 262:1883-1886. doi: 10.1126/science.8266079

Dietz KJ, Baier M, Krämer U (1999) Free radicals and reactive oxygen species as mediators of heavy metal toxicity in plants. In: Prasad MNV, Hagemeyer J (eds), Heavy metal stress in plants, pp.73-97. Springer, Berlin, Germany.

Ebbs SD, Bushey JT, Bond BS, Ghosh RS, Dzombak DA (2006) Cyanide phytoremediation. In: Dzombak DA, Ghosh RS, WongChong GM (eds), Cyanide in water and soil, pp 479-500. Taylor and Francis, Boca Raton, USA.
Ebbs SD, Bushey J, Poston S, Kosma D, Samiotakis M, Dzombak D (2003) Transport and metabolism of free cyanide and iron cyanide complexes by willow. Plant, Cell and Environment 26:1467-1478.

Ebbs SD, Kosma DK, Nielson EH, Machingura M, Baker AJM, Woodrow IE (2010) Nitrogen supply and cyanide concentration influence the enrichment of nitrogen from cyanide in wheat (Triticum aestivum L.) and sorghum (Sorghum bicolor L.). Plant, Cell and Environment 33:1152-1160.

Ebbs SD, Piccinin RC, Goodger JQD, Kolev SD, Woodrow IE, Baker AJM (2008) Transport of ferrocyanide by two eucalypt species and sorghum. International Journal of Phytoremediation 10:343-357.

Galis I, Matsuoka K (2007) Transcriptomic analysis of salicylic acid-responsive genes in tobacco by-2 cells. In: Hayat $S$, Ahmad A (eds), Salicylic acid: a plant hormone, pp. 371-396. Springer, The Netherlands.

Giannopolitis CN, Ries SK (1997) Superoxide dismutase. I. Occurence in higher plants. Plant Physiology 59:309-314. doi: 10.1104/pp.59.2.309

Goudey JS, Tittle FL, Spencer MSA (1989) A role for ethylene in the metabolism of cyanide by higher plants. Plant Physiology 89:1306-1310.

Goulden PD, Afghan BK, Brooksbank P (1972) Determination of manogram quantities of simple and complex cyanides in water. Analytical Chemistry 44:1845-1849.

Halkier BA, Møller BL (1990) The biosynthesis of cyanogenic glucosides in higher plants. Identification of three hydroxylation steps in the biosynthesis of dhurrin in Sorghum bicolor (L.) Moench and the involvement of 1-ACl-nitro-2-(p-hydroxyphenyl)ethane as an intermediate. Journal of Biological Chemistry 265:21114-21121. 
Hayat S, Ali A, Ahmad A (2007) Salicylic acid: biosynthesis, metabolism and physiological role in plants. In: Hayat S, Ahmad A (eds), Salicylic acid: a plant hormone, pp. 1-14. Springer, The Netherlands.

Kittock DL, Law AG (1968) Relationship of seedling vigor to respiration and tetrazolium chloride reduction by germinating wheat seeds. Agronomy Journal 60:286-288.

Machingura M, Ebbs SD (2010) Increased $\beta$-cyanoalanine synthase and asparaginase activity in nitrogen-deprived wheat exposed to cyanide. Journal of Plant Nutrition and Soil Science 173:808-810.

Machingura M, Sidibe A, Wood AJ, Ebbs SD (2013) The $\beta$-cyanoalanine pathway is involved in the response to water deficit in Arabidopsis thaliana. Plant Physiology and Biochemistry 63:159-169.

Mauricio R (2000) Natural selection and the joint evolution of tolerance and resistance as plant defense. Evolutionary Ecology 14:491-507.

Maxwell DP, Nickels R, McIntosh L (2002) Evidence of mitochondrial involvement in the transduction of signals required for the induction of genes associated with pathogen attack and senescence. Plant Journal 29:269-279.

McCutcheon SC, Schnoor JL (2003) Overview of phytotransformation and control of wastes. In: McCutcheon SC, Schnoor JL (eds), Phytoremediation, transformation and control of contaminants, pp. 3-4. Wiley-Interscience, New York, USA.

Mittler R (2002) Oxidative stress, antioxidants and stress tolerance. Trends in Plant Sciences 7:405-410.

Norman C, Howell KA, Millar AH, Whelan AH, Day DA (2004) Salicylic acid is an uncoupler and inhibitor of mitochondrial electron transport. Plant Physiology 134:492-501.
Rausher MD (1992) Natural selection and the evolution of plant animal interactions. In: Ruitberg BD, Isman MS (eds), Insect chemical ecology: an evolutionary approach, pp. 20-28. Chapman and Hall, New York, USA.

Rhoads DM, McIntosh L (1992) Salicylic acid regulation of respiration in higher plants: alternative oxidase expression. Plant Cell 4:1131-1139.

Samiotakis M, Ebbs SD (2004) Possible evidence for transport of an iron cyanide complex by plants. Environmental Pollution 127:169-173.

Taiz L, Zeiger E (2002) Plant physiology. Sinauer Associates Inc., Sunderland, UK.

Tittle FL, Goudey JS, Spencer MS (1990) Effect of 2,4-dichlorophenoxyacetic acid on endogenous cyanide, beta-cyanoalanine synthase activity, and ethylene evolution in seedlings of soybean and barley. Plant Physiology 94:1143-1148.

Tsang EW, Bowler C, Hérouart D, Van Camp W, Villarroel R, Genetello C, Van Montagu M, Inzé D (1991) Differential regulation of superoxide dismutases in plants exposed to environmental stress. Plant Cell 3:783-792.

Van der Straeten D, Chaerle L, Sharkov G, Lambers H, Van Montagere M (1995) Salicylic acid enhances the activity of the alternative pathway of respiration in tobacco leaves and induces thermogensity. Planta 196:419-421.

Xie Z, Chen Z (1999) Salicylic acid induces rapid inhibition of mitochondrial electron transport and oxidative phosphorylation in tobacco cells. Plant Physiology 120:217-226. 